\title{
SIR GEORGE BAKER AND THE DEVONSHIRE COLIC
}

by

\section{R. M. S. McCONAGHEY}

The Must, of palid Hue, declares the Soil

Devoid of Spirit; wretched He, that quaffs

Such wheyish Liquors; Oft with Colic Pangs,

With pungent Colic Pangs distressed he'll roar,

And toss, and turn, and curse th'unwholsome Draught.

John Philips*

JohN Philips was not a Devon man and the colic which he described with such evident personal feeling was not the Devonshire colic. In the eighteenth century the cider making counties of England were the shires of Devon, Hereford and Gloucester.

Cider was being made in Devonshire in the thirteenth century. At the beginning of the eighteenth century, when Defoe visited the county he remarked on the large quantity of the beverage that was annually sent to London. The best cider has for many, many years, come from that part of the county which is called the South Hams; an area roughly enclosed by the river Dart running down to the sea from Totnes, by the foothills of Dartmoor in the north, and by the deep estuaries of Plymouth harbour to the west. It is a land richly intersected with small streams, hardly worthy to be called rivers, which run through deep ravines south to the open Channel: it is a land rich in pasturage, but difficult to cultivate; a land where orchards, in the shelter of the overhanging hills, flourish; where the almost perpetual moisture ensures that the ripe fruit is full and juicy. In 1865 this district was producing an average of ten hogsheads of cider an acre. ${ }^{1}$

This South Hams countryside was the childhood home of three boys who were to make their mark on the medical world of their day. John Huxham (1692-1768) was born and educated at Totnes; William Battie (1704-1776), the mad-house doctor, was born in Modbury; George Baker, the son of the Reverend George Baker, the vicar of Modbury, and Bridget his wife, was born there on 8 February 1723. The young Baker was educated at Eton and at King's College, Cambridge, where he graduated M.A. in 1749, became a Fellow, and was made an M.D. in 1756. When he left Cambridge he set up in practice in Stamford in Lincolnshire; according to Munk, on the invitation of a large number of friends, but this situation was too limited for the exertion of his talents, and about the year 1761 he removed to London. ${ }^{2} \mathrm{He}$ became a Fellow of the College of Physicians, was Censor four times, Harveian orator, elect and, finally, President from 1785-1795. In succession he was appointed physician to the Queen's household, physician-in-ordinary to the Queen and physician-inordinary to King George III. He was created baronet in 1776. He was a Fellow of the Royal Society and of the Society of Antiquaries. In 1789 he was elected President

* Cyder. A poem, in two books, London, 1708. 


\section{R. M.S. McConaghey}

of the Society for the Relief of Widows and Orphans of Medical Men in London and vicinity. $^{3}$

When George III showed the first signs of his mental illness in 1788, Sir George Baker was the only doctor in attendance, and, after what was described as a sharp bilious attack, he recommended a visit to the spa at Cheltenham. Though he did not accompany the king he kept in touch with him by letter. On 19 July 1788, in reply to a letter from His Majesty he expressed his satisfaction that 'the water', as far as a trial of it had been made, 'seemed to succeed' and wisely added 'with respect to the quantity of Cheltenham water which is proper to drink, no one except the drinker can possibly determine it'. ${ }^{4} \mathrm{He}$ was in attendance on the king during the whole time of his illness, although his place was much usurped by the Willises, father and sons. For each visit to Kew he received thirty guineas and the total for all his attendances amounted to 1,300 guineas. $^{5}$

Sir George Baker must have been a man of quite outstanding attainments. His son, in a memoir attached to his collected works and published in 1818, says 'His great delight was on objects of literature, and in the society of literary characters, among whom his talents were conspicuous. He was remarkable for a most tenacious memory and for the elegance of his classical taste ...6 When Baker first came to London there was a large and distinguished circle of Devonians and he numbered among his patients Sir Joshua Reynolds, who mentions dining with him on several occasions. ${ }^{7}$ The doggerel reply of Goldsmith to an invitation to dine with him is well known:

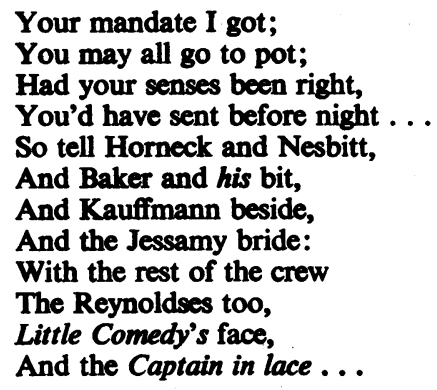

A contemporary wrote in 1793 that 'Sir George Baker has long enjoyed the wellearned reputation of writing Latin with a degree of purity and elegance, which distinguishes the compositions in that language of few of his contemporaries' ${ }^{8}$ To him the poet Gray is said to have dedicated the 'Elegy written in a country churchyard' when he was still at Cambridge.* Thomas Percival of Manchester dedicated to him his code of medical ethics 'which he has honoured with his sanction, and improved by his communications ....'

We know little of his method of practice. He seems to have been a believer in the virtues of spa treatment and was in the habit of sending his patients into south Devon when a change of air was indicated. ${ }^{9}$

The following letter, written to E. Davey Esq., of Yexford in Suffolk on 24 October

* Gentleman's Magazine, 1793, p. 590. I can find no evidence of this; the earliest editions in the British Museum are those printed by Dodsley and dated 1751. None of these bears any dedication. 


\section{Sir George Baker and the Devonshire Colic}

1788 at a time when he must have been much employed in tending the King and coping with the politicians, gives not only an indication of his therapeutic way but also is an example of his straightforward epistolary style. Eleazar Davey was Sheriff of Suffolk in 1770.

I am sorry that it has not been in my power to give you a speedier answer on the subject of poor Lady Carbery's illness. My time has almost wholly been spent on the road. I well know that her Ladyship is a great rake; and she knows by sad experience how much she suffers for being so. Your Apothecary appears to me to have treated her with great judgment. Her Ladyship is aware how necessary it is to keep the bowels open. If the aloes agrees there is no medicine more proper for that purpose. Whether the lancet be or be not proper under the present circumstances, is what I cannot determine, and I am ignorant of the present state of the pulse. $L d C$. and I often dispute about it. If the head be troublesome, she must either be cupped, or bled. This being done, I advise LdC. to take thrice a day a tea-spoon-full of the volatile tincture of Valerian in a cup of cold Valerian tea. But why is not her Ladyship at Bath? I strongly pressed her to go thither; and she promised compliance.

My wife desires to join with me in best compts to Mrs. Davey and yourself, with best wishes to the patient.

I have the honour to be Dear Sir,

Your most obedient and very faithful Servant

G. Baker.10

Jermyn St.

24 Oct 1788

In their childhood both the young Huxham and the young Baker must oftentimes have seen the apples gathered off the trees and raked into large heaps and watched the heaps carted to the mills to be ground down to pulp. They would see the 'cheese' piled up under straw in the granite mill and the 'must' expressed. They would see the juice stored in the large open vessels and watch for the head to rise before the 'must' was transferred to the casks. They might help in the racking of the vessels and watch for the fermentation to cease.

Huxham would have been more familiar with all this, for he received his education locally, before going to Leyden to sit at the feet of Boerhaave and so to learn clinical medicine in a manner impossible in the England of his day. When he returned to Plymouth to start in practice he kept notes of the weather and the prevailing diseases. ${ }^{11}$ He noted the occurrence of a special kind of colic which appeared in the autumn at a time when the new cider began to be consumed. But the colic had been known long before this. William Musgrave had mentioned it in his work on arthritis ${ }^{12}$;

In Devonshire there is another sort of colic arising from the rough and acid cider, drank there in too great quantity. That the cider is the cause is manifest from hence, that this colic infests only those who use themselves to that liquor, and that less or more, in proportion as they make use of it. So that in those seasons, which abound with cider, the disease prevails most, and grows epidemic. On the contrary, when Pomona withholds a plenty, it more rarely makes an appearance.

In his Observations of the Air and Epidemic Diseases, Huxham had cause to mention the curious outbreaks of colic at about the same season nearly every year. In 1739 he published his essay on the epidemic of 1724, De morbo Colico Denmoniensi* in which he describes the symptoms and signs of the disease including the wrist-drop:

* Opusculum de Morbo Colico Damnoniorium eque maxime Epidemico Anno MDCCXXIV, London, 1739. B.M. copy bound with Observationes de Aere et Morbis Epidemicis. Norman Moore in D.N.B. gives the date as 1752 . 


\section{R. M.S. McConaghey}

This disease began its attack by an excessively tormenting pain in the stomach, and epigastric region, with an unequal weak pulse, and coldish sweats; the tongue in the meantime was coated with a greenish, or brown, mucus, and the breath was most offensive. An enormous vomiting soon followed, for the most part of exceeding green bile, sometimes black, with a great quantity of phlegm excessively acid and very tough; nay the foul matter brought up was oftentimes so very acrid, that, by excoriating the throat and the oesophagus, it was tinged with blood, and created a difficulty and pain in swallowing ... Things continuing in this state for a day or two, the belly became extremely bound, neither answering to the most drastic purges, or sharpest clysters, the latter coming off without wind or stool, the former being soon vomited. The vomiting abating somewhat, the pain descended, and most grievously tortured the umbilical region, and small of the back, so that you would have thought the patient actually laboured under a nephritic paroxysm and the rather as a suppression of the urine now also comes on, and yet a perpetual desire of that discharge is urgent; nay very frequently there is a most troublesome sense of weight in the perineo, as if from an incumbent stone.

Huxham goes on to describe the muscular pains, the terrible pains in the bones, the weakness and the subsequent paralysis that brings to a fatal conclusion severe cases of lead poisoning. In most cases the amount of lead consumed can have only been small for the mortality was not great. Huxham thought that the disease was caused by the consumption of large quantities of fresh, rough cider, and this was the commonly accepted cause for the colic of Devonshire when Baker made his investigation and proved that the disease was due to lead poisoning.

\section{SIR GEORGE BAKER'S INVESTIGATION OF THE COLIC}

In the introductory paragraphs of his short classic*, Baker stated that much labour and ingenuity had been expended on remote cases of disease whilst those which are obvious and evident and which must necessarily be acknowledged as soon as stumbled upon, have been too frequently overlooked and disregarded. 'Men', he remarked, 'are apt to be partial to their own conceits . . . and seldom forget opinions at the bedside which have been the result of much contemplation at home.'

After quoting from Musgrave and Huxham, he drew attention to the similarity of the colic of Devonshire to that of lead poisoning. 'When I have considered, that there is not the least analogy between the juice of apples, and the poison of lead; and that this colic of Devonshire is precisely the same disease, which is the specific effect of all saturnine preparations; it has not seemed to me at all probable that two causes, bearing so little relation to one another, should make such similar impressions on the human body.' He dismissed Huxham's theory that acid was the cause of the colic.

... if Cyder is the cause of this disease, as being an acid, why is the colic of Poitou very little known in the western countries, where the Turks, whose religion obliges them to abstain from wine, drink every day large quantities of an acid sherbert? Does the experience of jockeys, who in order to reduce themselves to a certain standard of weight by sweating, are said to drink largely of vinegar, strengthen such an observation? Do we find it true that children and valetudinary people, and particularly chlorotic girls, whose primae viae abound with acid, are on that account subject to this colic? Is not a Diarrhoea, or Cholera, the ordinary effect of eating unripe fruit immoderately? What reason can be given, why the poorer inhabitants of the counties of Worcester, Gloucester and Hereford, who use, as their common drink, a weak acid cyder, are subject to no such colic? [After a series of further questions of a similar kind, Baker continued] And lastly is it reasonably to be suspected, that the essential salt of a vinous liquor can raise such

* An Essay Concerning the Cause of the Endemical Colic of Devonshire, which was read in the theatre of the College of Physicians, in London, on the twenty-ninth day of June 1767. London printed by J. Hughs, near Lincoln's-Inn-Fields, 1767. Also printed in Med. Trans., Vol. 1, p.201, 1768. 


\section{Sir George Baker and the Devonshire Colic}

tumults in the bowels, whether by corrupting the bile or otherwise; when it is vulgarily known, even among the miners in Derbyshire, that patients, afflicted with this same disease, do not receive a more immediate, or a more important relief from any medicine whatever, than by taking large and repeated doses of this very essential salt, the Cremor Tartar; and when it appears that Dr. Hillary greatly depended on it for the cure of dry-belly-ache in the West Indies?*

Baker next quoted some experiments by German doctors on the effects of feeding dogs on vinegar and on litharge dissolved in and boiled in vinegar, which proved nothing. He then went on to describe the epidemiology of the disease:

Upon enquiry, I find that this disease is common all over the county of Devon; but that it particularly infests those parts of the county, where the greatest quantities of Cyder are made. I likewise find that it is not only common among the lower class of inhabitants; but that it is much more frequent among people of all ranks, than in other parts of England; and that it is not entirely confined to the autumnal season.

He gave an account of the admissions to the hospital at Exeter since 1762:

$\begin{array}{lr}\text { From Sept. } 1762 \text { to Sept. } 1763 & 72 \\ \text { Sept. } 1763 \text { to Sept. } 1764 & 75 \\ \text { Sept. } 1764 \text { to Lady-day } 1766 & 86 \\ \text { Lady-day } 1766 \text { to July 6, } 1767 & 52 \\ & \end{array}$

'of this number 209 were cured'

Dr. John Andrewt who supplied these figures informed him that the patients were brought in from all parts of the county, but chiefly from those parts where cider was most made. The most violent symptoms of the disorder, such as the pains and costiveness, were generally removed before the patient was admitted, and 'nothing commonly remains but a paralytic weakness in the arms'.

Some of the old record books of the Royal Devon and Exeter Hospital are preserved. ${ }^{18}$ From these there appears to have been little difference in the number of admissions in the years before the publication of Baker's paper and the years after. Thus a count of the number of colics and abdominal palsies admitted in the months 28 July 1760 to 19 February 1761 was 25 (made up of ten cases of pain in the stomach, eight of pain in the bowels, one of pain in the belly, one colic, one colic with obstruction; there were also two cases of palsy of the hands and one of the arms included in

- In 1745 Thomas Cadwalader (1708-1779), of Philadelphia, who had been a pupil of Cheselden, drew attention to the similarity of the 'dry-gripes' of West India and the disease called the colica Pictonum so named because it was most frequently found in Poitiers. 'I have seen in England two instances of the success attending the method here laid down for the dry-gripes in the Cholera pictonum, arising from the Fumes of White-lead ... We frequently observe persons in the dry-gripes to lose the use of their limbs (the Ancles and Wrists becoming exceeding weak, and the balls of their Thumbs sinking) either by the acrimony of the humours, or the Use of Strong Stimulants.'

Cadwalader, Thomas, An Essay on the West-India Dry-gripes; with the Method of Preventing and Curing that cruel distemper. To which is added, An extraordinary case in Physic, Philadelphia, Printed and sold by B. Franklin, 1745 .

+ Dr. John Andrew was one of the original physicians appointed to the Royal Devon and Exeter Hospital when it opened in 1741. He died in 1772, aged 63. He had the distinction of admitting the first two patients to the hospital. He was said to have been 'a man of learning, of polished address, unremitting in his professional exertions'. He introduced into Exeter, under the sanction of Dr. Alured Clarke, the practice of inoculation against smallpox, and he recorded in a pamphlet the prejudice he had to encounter, and the secrecy he found it necessary to observe. (Harris, J. Delpratt, The Royal Devon and Exeter Hospital, Exeter, Published for the Hospital Committee by Eland Brothers, 1922, p.46.) 


\section{R. M. S. McConaghey}

this total as probably due to lead and a number of unspecified palsies not so included). The total number of admissions was 597, over the same period of time. In the year 1769, two years after Baker's paper was published there were thirteen cases of a similar nature out of a total of 589 admissions; six pains in the stomach, one pain in the bowels, three simple colics, one with a swollen knee, and one with palsy. These figures are not very revealing. The periods taken for analysis were the last half of the year as it was commonly accepted that the colic appeared soon after the new cider began to be drunk. There is a gap in the records after March 1761 until July 1768. It may be only a coincidence that it is precisely for these years that John Andrew provided statistics.

Eighty patients were admitted to the Bath hospital in the course of 1766, 40 of whom were cured and 36 sent away greatly relieved. The proportion of such patients from Devonshire to that of the counties of Hereford, Gloucester and Worcester was generally one to eight.

Next, Baker gave an account of correspondence that he had had with Dr. Wall of Worcester in which Wall said that so far as he knew the inhabitants of Hereford, Gloucester and Worcester were not subject to the colic of Poitou or any other endemic disease, 'unless it be the rheumatism; which I think the inhabitants of Herefordshire are more liable to, than those of some other counties. There is no Lead, which can give occasion to that colic, used in any part of the Apparatus for grinding or pressing the apples, or fermenting the liquor.' Wall is meticulous to quote exceptions; there was the farmer who ran out of casks and filled a large leaden cystern with new cider, '. . . all who drank of it were affected by it as the lead workers usually are. We had eleven of them, at one time, in our Infirmary.' He had also had two or three patients with colic caused by their having drunk cider made in a press covered over with lead.

Baker passed on to consider the method of making cider in Devonshire. 'The large circular trough, in which the apples are ground, is generally composed of several pieces of moor-stones, cramped together with iron, some melted lead being poured into the interstices. It frequently happens that these stones, which are thus to be joined, are unequal, and do not correspond with each other; so that considerable chasms are left between them; and these chasms are filled up with lead.' In several parts of the county it was, he said, common to line the cider presses entirely with lead in order to prevent their leaking; or to make a border of lead quite round the press, in order to receive the juice of the apples, and to convey it into a vessel made of wood or stone and placed immediately underneath. In many places where these methods were not used it was common to nail sheet-lead over any cracks or joints in the presses; and to convey the juice of the apples from the presses in leaden pipes; leaden weights were sometimes placed in the casks to prevent the cider from going sour.

After giving this preliminary evidence, Baker reported on his experiments. He obtained some of the expressed juice of the apples as it flowed from a press which was lined with lead in the parish of Alphington near Exeter. On this must be made several experiments 'by means of the atramentum sympatheticm or liquor vini probatorius described by Newman*; and of the volatile tincture of sulphur.'

\footnotetext{
* Caspar Newman, author of The Chemical Works, first edition, 1749.
} 


\section{Sir George Baker and the Devonshire Colic}

These observations entirely satisfied him that the 'must' contained lead, but he proceeded to make further experiments, this time in London. He took back with him from Exeter some of the same 'must' and some cider which the maker had assured him contained no lead in the making except that which was used to line the press. In his further experiments he had the assistance of 'Dr. Saunders', and ingenious gentleman, who teaches chemistry'.

Baker explained that lead when united with wine was considered to be in the form of saccharum Saturni-sugar of lead. 'By attentively observing the variety of changes produced by certain bodies when added to a solution of saccharum Saturni; and by applying these observations to the wines, which are the most frequent subjects of this adulteration, Chemists have been enabled to detect such frauds, wherever they have existed.' In the experiments which are next described the cider was exposed to various substances: it was soaked onto clean paper and exposed to the fumes of volatile tincture of sulphur; a darkish colour ensued which could not be reproduced by any other substance than lead, nor was it obtained with Hereford cider. Hepar sulphuris was next placed in Devonshire cider and turned it black in a few minutes and a few drops of hepar sulphuris when added to a small quantity gave a very dark precipitation.

These experiments, there were five in all, were of devastating simplicity, and Baker summed up in these words: 'It is presumed that, the presence of lead in the cyder of Devonshire being demonstrated, there is no one, at this time of day, likely to revive the argument of Seerup, and still insist on the deleterious quality of the acid: For a poison is discovered, which is experimentally known to be adequate to all these dreadful effects, so pathetically described by Dr. Huxham.' Not to leave any avenue for argument, Baker took up a statement of Huxham who found difficulty in accounting 'why the juice of apples in one year produces a costive belly, with violent colical pains, but in another, a loose belly with scarce any gripes attending'. On this Baker quoted James Wilson $†$ who gave an account of a disease called by the miners mill-reek, which all the inhabitants of Lead-Hills were subject to, "but particularly those, whose daily business it is to melt down the lead ... in the first stage of this disease, a diarrhoea sometimes makes a cure'.

Baker's peroration read:

May not I presume to hope, that the present discovery of a poison, which has for many years exerted its virulent effects on the inhabitants of Devonshire, incorporated with their daily liquor, unobserved, and unsuspected, may be esteemed by those, who have power, and who have opportunities to remove the source of so much mischief, to be an object worthy of their most serious attention? I have long lamented, that a county which is distinguished by some peculiar blessings, should likewise be distinguished by a peculiar calamity, as it were in consequence of its fertility. The subject therefore having appeared to me important, I have spared no pains in this

* William Saunders was born in Banff in 1743 and graduated from Edinburgh, where he was on friendly terms with Cullen. After receiving his doctorate in 1765, he settled in London. The help he gave to Sir George Baker when he had only been in London for a year was probably instrumental in starting him on a distinguished career; he became physician to Guy's hospital, was Censor to the College of Physicians four times, Gulstonian lecturer and Harveian orator. In 1807 he was appointed physician extraordinary to the Prince Regent.

$t$ James Wilson was a surgeon at Durrisdeer in Lanarkshire and attended the workers in the smelting mills at Leadhills. He published 'An account of the disease called Mill-Reek' in the Scots Magazine, 1754, 16, 287. See 'The mill-reek and the Devonshire colic' by Andrew Meiklejohn in Brit. J. Industr. Med., 1954, 11, 40. 


\section{R. M. S. McConaghey}

investigation; and I am insured of my reward in the consciousness of having endeavoured to preserve my countrymen and fellow-creatures from one of the most dreadful diseases, incident to the human body.

This essay will probably be hereafter published in a medicinal collection. Some copies of it are now printed, with a particular view to giving to the inhabitants of the county of Devon the earliest intimation of their danger; in order that they may take the proper steps to preserve their health, and to secure the value of their property.

The medical collection to which Baker was referring was the projected publication of Medical Transactions by the College of Physicians. It was proposed that papers should be read at weekly intervals by the fellows and even by licentiates.* The essay on the Devonshire colic was published in the first volume and was followed by a whole series of papers on the subject of lead poisoning. The paper as it appeared in the Transactions differs in some detail from that which was sent into Devon; Baker evidently thought that he could be more outspoken in the College publication; thus he hinted at other causes of contamination less creditable than that put forward in the earlier essay and says: 'It is very certain, that, in various parts of the county of Devon, there are those, who possess certain secrets for the management of cyder; the general object of which secret is, to correct the sourness and austerity of that liquor . . . I have several times discovered marks of a solution of lead in the English made wines.' Lead had been recommended in a little work by William Graham on the Secrets belonging to the Mystery of Vintners the second edition of which was published in about 1764. This evil practice continued for some time after the exposure of it by Baker, for Thomas Percival who wrote on The poison of lead (1774) quoted the advice of John Townsend in The universal cook:

'To hinder wine from turning. Put a pound of melted lead, in fair water, into your cask pretty warm, and stop it close.'

Percival comments that it must be supposed that Townsend was ignorant of the poisonous quality of lead; 'but he is certainly deserving of censure for presuming to give receipts without better information. And if he, or his brethren vintners have practised the method which he recommends, they are justly chargeable with all the mischiefs such detestable arts must produce. The adulteration of wine is indeed an evil so general, and so dangerous in its consequences, that it is to be hoped the legislature will interpose to prevent it.' Baker read his paper at the College on 29 June 1767. On 13 July, he was back in Warwick Lane with 'An examination of several means, by which the poison of lead may be supposed frequently to gain admittance into the body, unobserved and unsuspected.' In this paper he gave an account of lead poisoning both in the acute and chronic forms. He quoted Zeller on the effects of wine impregnated with litharge on some people who drank only small quantities of it. After some references to France, Germany and Holland he continued: 'The custom which prevails in many parts of this country, of keeping milk in leaden vessels, seems liable to similar objection.' He quoted Erasmus Darwin of Lichfield as telling him of experiments made of brine used to salt beef and kept in a leaden cistern. Darwin had studied the lead content of various vessels used in cooking and condemned the practice of 'the

- The year 1767 was the year of the seige of the College by licentiates who were protesting at being excluded from full participation in the affairs of the College. At first the licentiates boycotted the Transactions but they soon lifted their prohibition and a large part of the Transactions was contributed by them. 


\section{Sir George Baker and the Devonshire Colic}

lower class of people, of baking tarts in a cheap kind of earthenware.' On the evidenc of Benjamin Franklin he stated that, in Boston forty years before, leaden worms wer used in the distillation of spirit with such deleterious results that a law was passec to put an end to the practice.

\section{THE RECEPTION OF BAKER'S ESSAY IN DEVONSHIRE}

Baker was well aware of the reception that his paper would receive in Devonshir and he confessed as much in the version published in the Transactions. Cider wa: exported from Devon to all parts of the British Isles. The people of Devon were ir no mood to have the quality of their chief export called into question; for, as recentl! as 1763, Lord Bute, the prime minister at the time, had forced through parliament : Bill to impose an excise duty of $10 \mathrm{~s}$. $0 \mathrm{~d}$. a hogshead on cider and perry, to be paic by the first buyer, and this had stirred up the most violent opposition, not in thi county only but all over the country. No fiscal question had raised so much oppositior since Sir Robert Walpole's Excise Bill thirty years before. Bute's effigy was burnt ir the market places and many broad sheets and lampoons were printed against him Some historians believe that it was the unpopularity that was then created that leac to his resignation. Quite naturally when doubts were cast on the purity of the cide from Alphington, it was feared that suspicion would be cast on all cider going out $o$ the county. Something had to be done to prevent this. Huxham was by now an olc man and he seems to have taken no active part in the controversy that followed Defence of the Devonshire cider was taken up by a Plymouth surgeon, Franci: Geach, M.D., F.R.S., and surgeon to the Royal Hospital at Plymouth, who publishec a pamphlet* in which he contended that the cause of the colic was much more likely to be due to the acid in the cider, as had been stated by Huxham, and he said tha there was the strongest reason to suppose that it must be owing, partly to the use 0 . crude fruit and its juice not well fermented, and partly also to some peculiar dispositior of the atmosphere, and consequently may be considered as an epidemical disease which rages, as well as the smallpox and measles, with greater or less violence at on time than another.' He remarked that there was scarce a farmer of fifty years old ir Devon who was not more or less troubled with rheumatism, and he attributed thi: sad state of affairs to the immoderate use of cider; not perhaps a high tribute to hi: neighbours nor a good advertisement for the cider that he was setting out to defend He pointed out that neuritic symptoms occurred in the poor inhabitants of Glouceste and Hereford, who drank weak cider and were not so subject to the colic as were the Devonians. He states 'that it was not uncommon (even in those counties), to mee deplorable objects, with their hands dangling, and, who by such imbicility, ari distinguished by the appellation of the danglers'.

Geach reproduced two letters from Mr. More, 'an eminent chemist in Jermyr Street', who said that Saunders had told him of the experiments and described wha he was doing. In More's view the lead was not extracted from the cider but was : contaminant derived from the shot which was used to clean the retorts. $f$

\footnotetext{
* Some observations on Dr. Baker's essay on the endemical colic of Devonshire, by Francis Geach surgeon at Plymouth and F.R.S.: In which are added some remarks on the same subject by the Rev Mr. Alcock. Audio alteram partam. London, 1767.

† According to a correspondent in the Gentleman's Magazine for 1798 (p. 305) More was late
} 


\section{R. M. S. McConaghey}

Geach appended to his pamphlet an essay by the Reverend Thomas Alcock*. Alcock had previously written against the tax on cider. $f$ He stated that the use of lead in lining the troughs was very unusual, and that many of the troughs had no lead in them at all. 'I never saw or heard of any such, till this gentleman informed me of the one at Alphington'. He 'wished that the essayist had made his trials from other and fairer specimens'. He suggested that the difference in colour produced in the experiments might be due to the greater acidity of the Devon apples, and says that the apple trees of Devon were more closely planted than those in the counties of Hereford, Gloucester and Worcester;

Much of the Devon fruit, must in consequence, not having equal advantage of the sun and wind, be green and crude, and the juice austere and sharp; the Hereford people are also more careful in collecting their apples; do not pound them till they are thoroughly mellowed and sweetened; and in doing this they do not throw them into large round heaps, as the custom is in the west country, whereby the interior part of the heap becomes musty and putrid, and gives a disagreeable smack to, and weakens the cider; but in broad flat heaps, of only about one foot in depth. I may mention too that some of our Devon cider, particularly what is made from a large proportion of sweet apples soon turns to a leaden or bluish colour on being exposed to the air.

Reverting back to the question of lead in the presses, he makes a telling point; 'I always thought', he says, 'that putty had been made of white-lead, oil and whiting ... . on enquiry the glaziers assure me that this is the usual composition of putty'.

Baker was not to be drawn into the controversy; he continued to read papers to the College of Physicians on various aspects of lead poisoning but took no further action, leaving it to William Saunders to defend his experiments. In November 1767 Saunders published his answer in the form of a letter to Dr. Baker. H† He signalized Geach's part of the pamphlet as ' . . a dull, uninteresting, uninstructive repetition of a vain unsubstantial theory, together with an addition of much false reasoning, from his own private stock, and an abundance of misrepresentation'. We cannot know whether Baker helped in the production of this paper; there is internal evidence that he was consulted in the course of its production. The pamphlet is a polished production with shafts of wit and ridicule. 'Geach', he writes, 'speaks very learnedly of the

elected secretary to the Society of Arts. This correspondent's version is that the experiments by Saunders were made on cider which had 'accidentally been long kept in bottles in which some shot had accidentally been left' and More wrote to Huxham who 'for reasons best known to himself, entrusted that letter to Dr. Geach, who printed it, as may be seen, in the pamphlet'. The writer of the letter in the Gentleman's Magazine comments scathingly on 'the justice and candour of Dr. Geach, and how much he scorned to arrogate to himself what did not truly belong to him ... 'Samuel More was secretary of the Society for the Encouragement of Arts, Manufactures and Commerce (the forerunner of the Society of Arts) for 29 years and died in 1799, "truly lamented by every person who had the pleasure of knowing him'. His funeral was attended by the Duke of Norfolk, president of the Society.

* Thomas Alcock (1709-1798) was born in Runcorn in Cheshire and educated at Brasenose College, Oxford, where he graduated M.A. in 1741. He was vicar of Runcorn but in his later years resided chiefly at St. Budeaux's near Plymouth. He published in 1752, Observations on the Defects of the Poor Law, and Remarks on two Bills for the better Maintenance of the Poor. His brother Natham studied medicine at Leyden, Edinburgh and Oxford and at the latter place gave unauthorized lectures in anatomy. He took his M.D. in 1749, practised a while at Oxford, before retiring to the more restful surroundings of Runcorn. His reputation as a wise physician was high.

t Thomas Alcock. Observations on that part of a late Act of Parliament which lay an additional duty on the Cyder and Perry. Sic vos non vobis mellificutis Apes. Virg. By Thomas Alcock, A.M. and a Cydermaker in Devonshire. (Undated).

$\mathrm{tt}$ An answer to the observations of Mr. Geach and to the cursory remarks of Mr. Alcock on Dr. Baker's essay on the Endemical Colic of Devonshire. In a letter from Dr. Saunders to Dr. Baker, London, Printed for E. \& E. Dilley in the Poultry, 1767.

(The date of this is given as 1768 in Munk and the D.N.B. There is no record of any other edition having been published, and a search of the principle libraries has not revealed one.) 

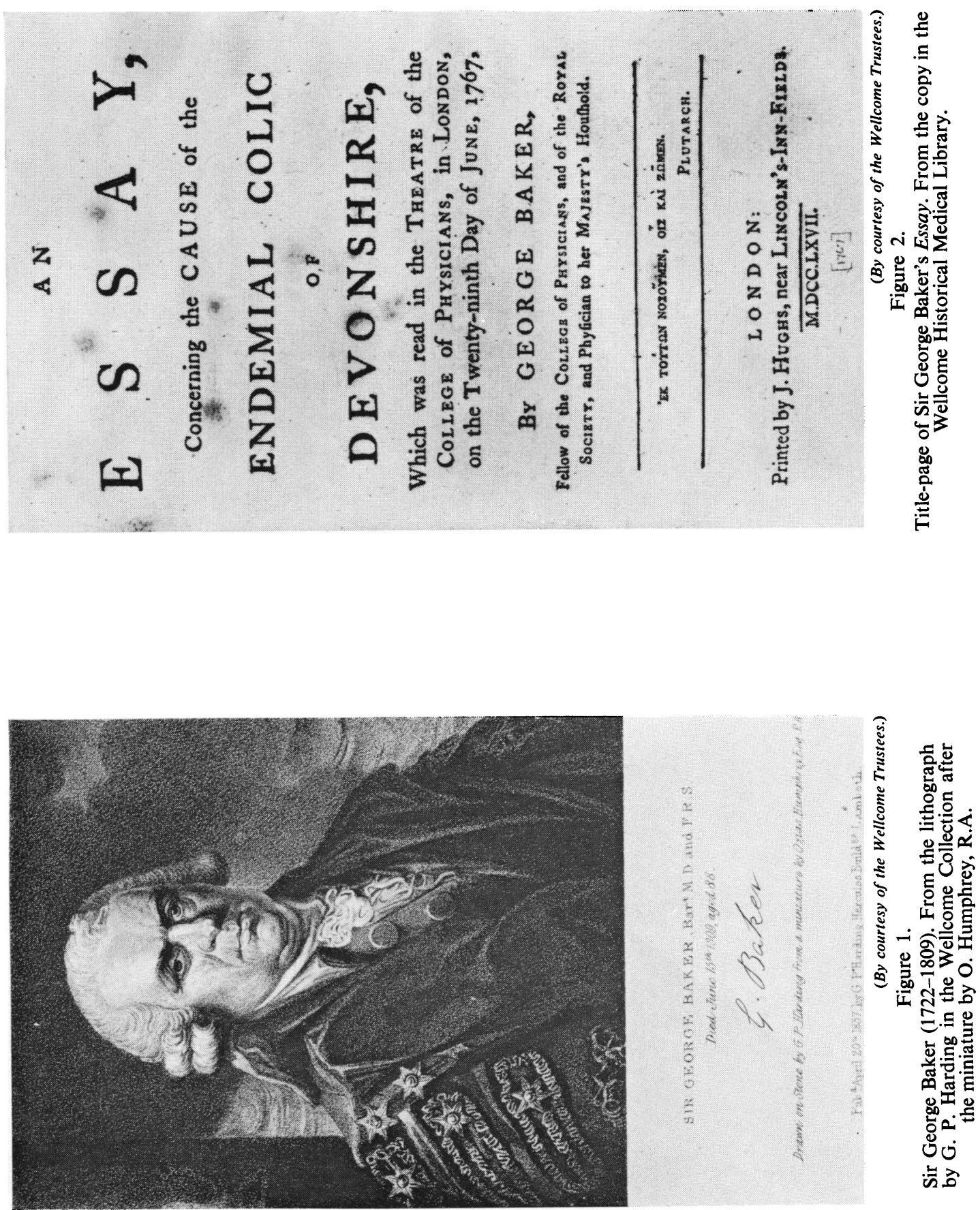


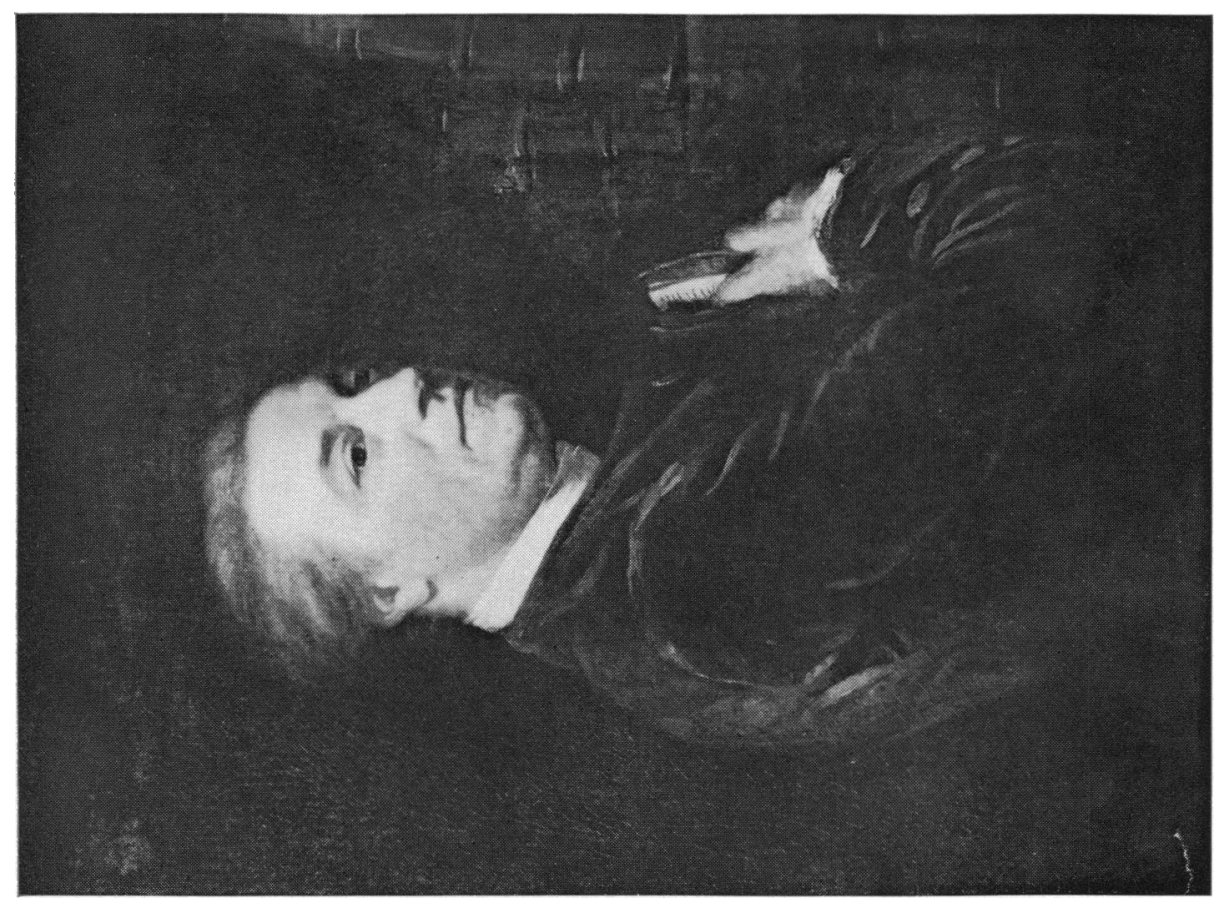

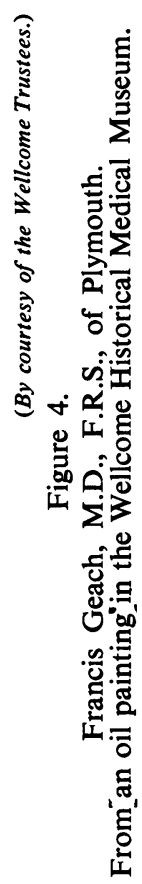
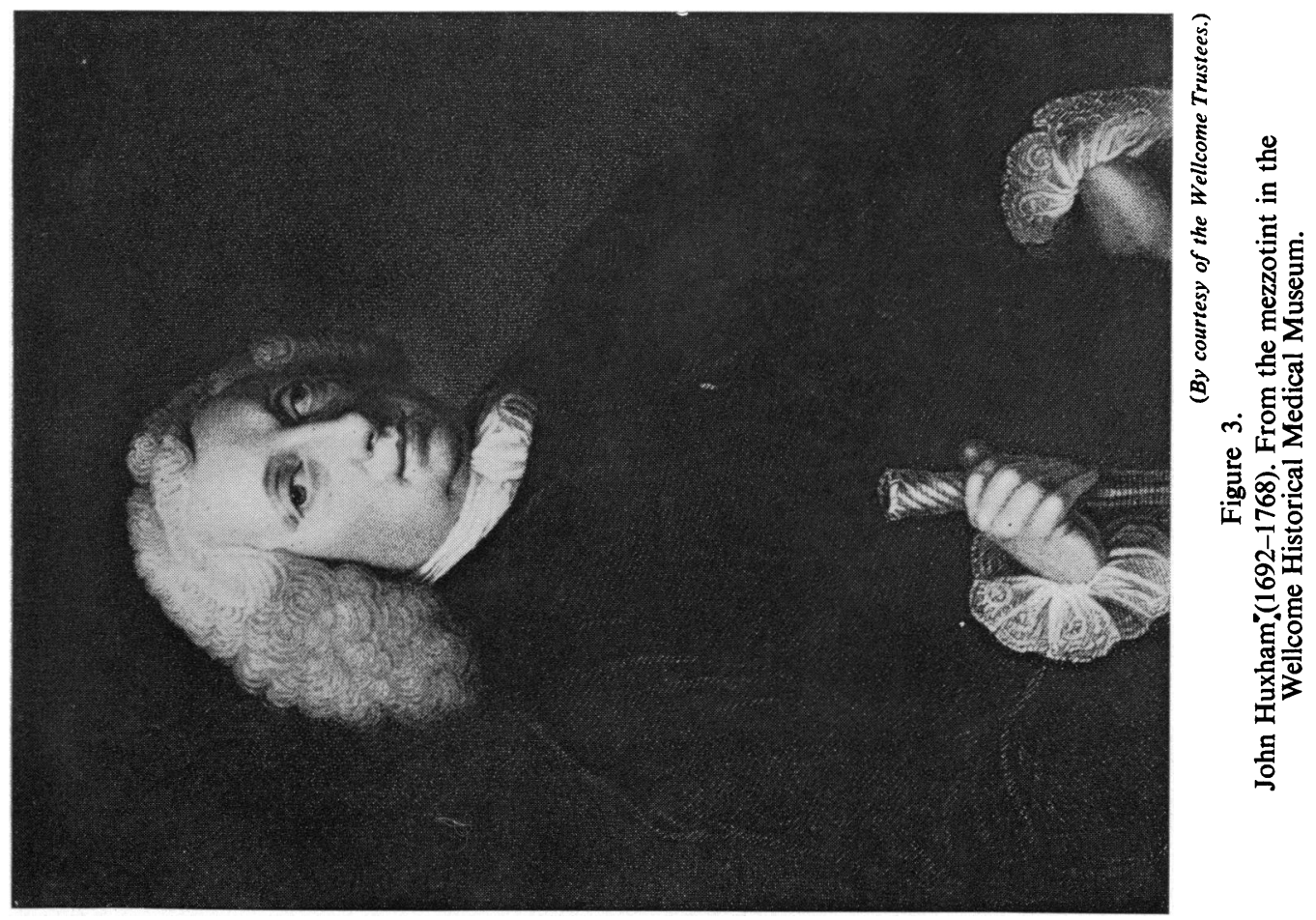


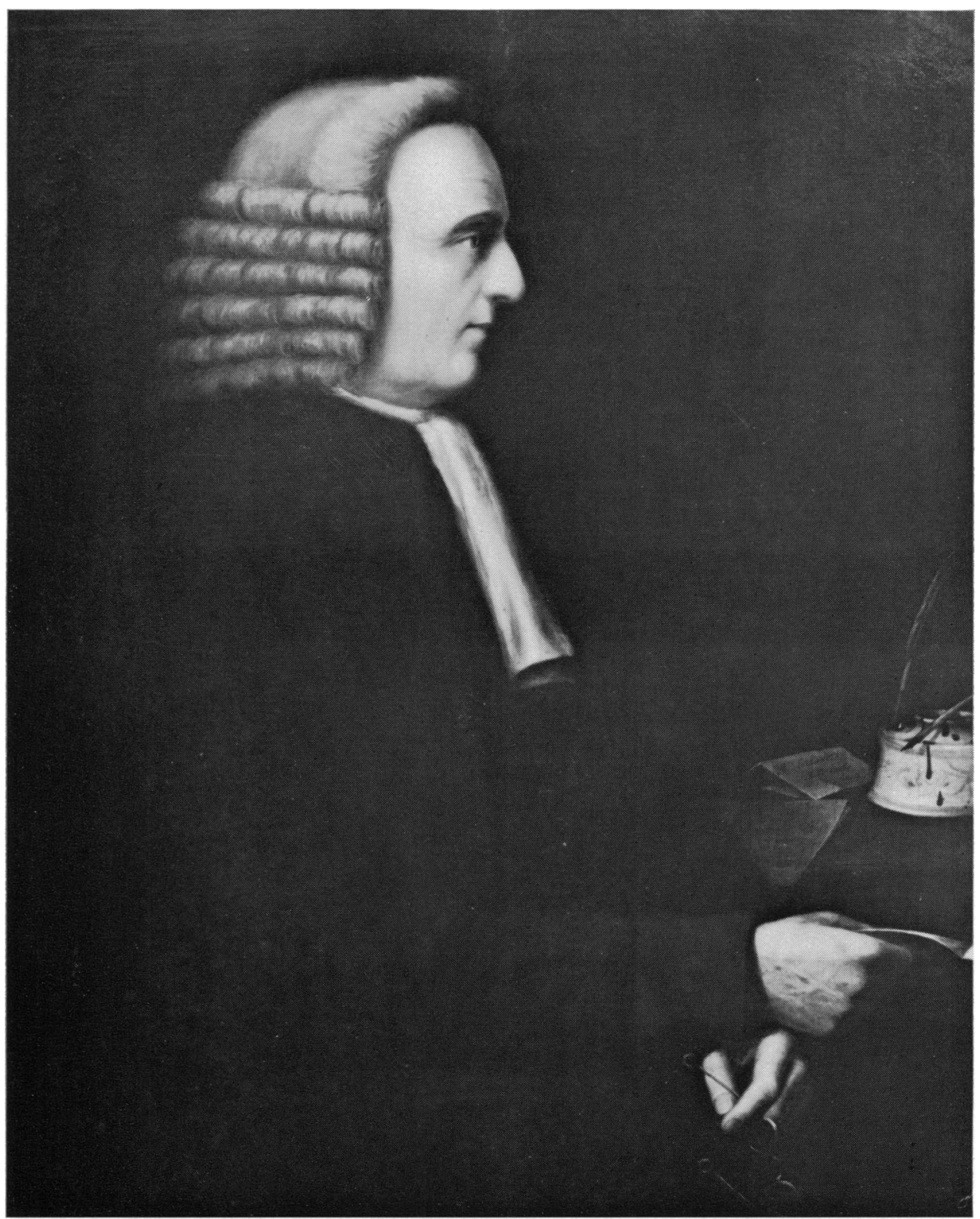

Figure 5.

(By courtesy of the Wellcome Trustees.)

William Cookworthy (b. 1705). From an oil painting in the Wellcome Historical Medical Museum. 


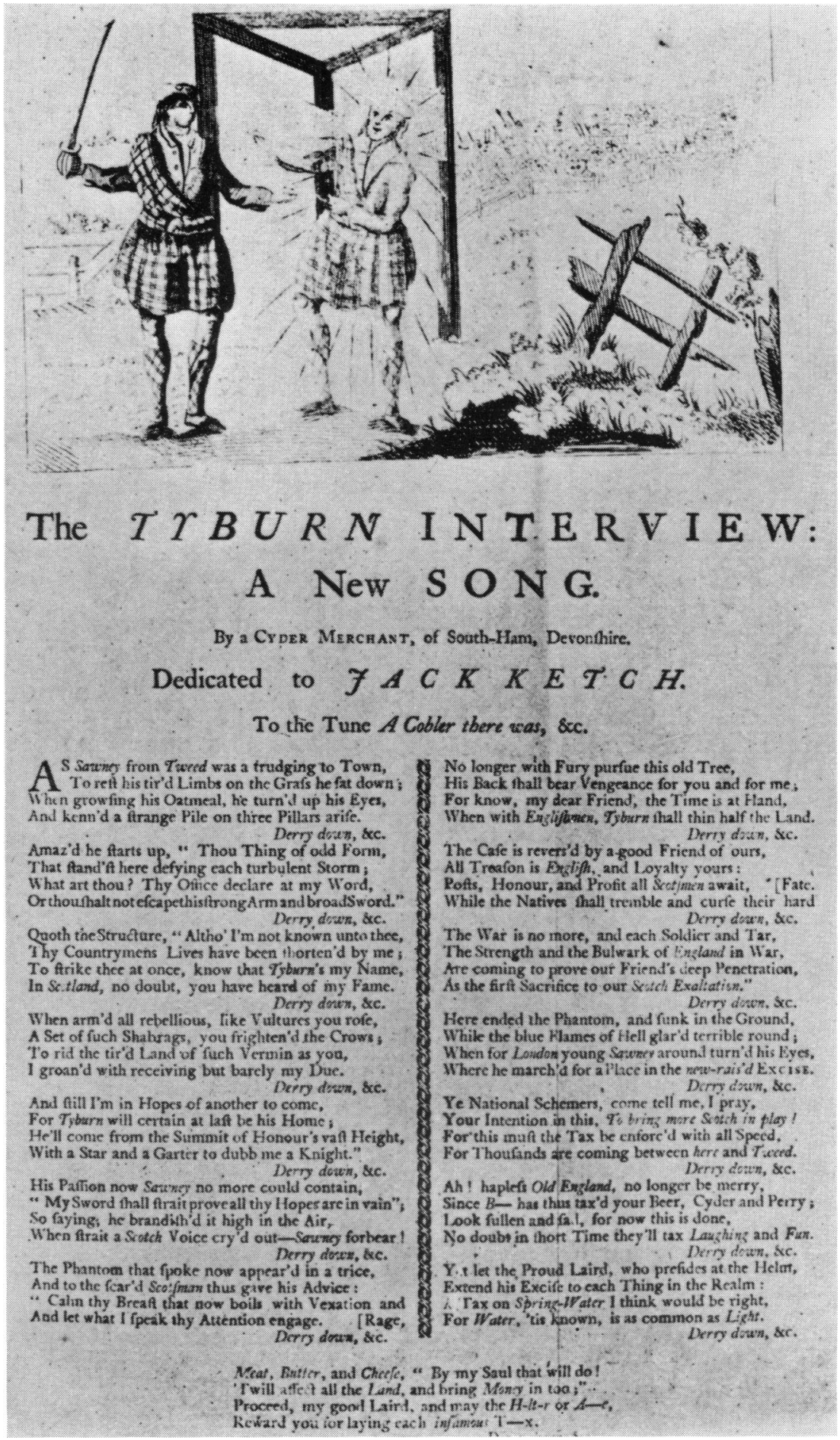

Figure 6. (By courtesy of the Wellcome Trustees.)

The Tyburn Interview, a New Song.

From the copy in the Wellcome Historical Museum and Library. 


\section{Sir George Baker and the Devonshire Colic}

'sulphur of fruits', quite a new principle, and not to be understood by anyone, not even by himself, I wish he had brought some proofs of its presence, and in what state it exists'. Not content in demolishing Geach's arguments he produced fresh evidence: 'It is likewise a common practice among the farmers of Dorsetshire, to buy from the apothecaries large quantities of Sacher. Saturni, with which they are known to sweeten their cyder. This I can affirm from the certain testimony of gentlemen of credit, who reside in that county.' He attacked Geach's statement that it could not be proved that sheet lead was nailed over any press in any part of Devon, except Alphington: 'What will this author say, if I reply, it can be proved, that in the year 1766, there were many such presses, in several parts of the county. It can be proved by certificate, which you [Baker] have shown me, that in three parishes only, there were at least thirty presses lined with lead. This is no hearsay or random assertion.' Saunders had a complete answer to the assertions of More that the lead was present in the form of shot. He said that he found in the extract of the 18 quarts of cyder he was assaying, a small quantity of malleable lead.

I immediately suspected this might arise from shot in the bottles; of this suspicion you had the earliest intelligence. I picked out all the lead carefully; and my own private assaying furnace not being in order, I carried it to be assayed at a place where I met with Mr. More: I told him what I was engaged in, and immediately hinted to him my suspicion regarding the accuracy of the experiment, and suggested the propriety, and urged the necessity of repeating it; however I proceeded in the assay, although I meant to lay no stress on it; this he knew perfectly well, as I told him, I would set about making another extract immediately; the result of the assay of which is referred to in your fifth experiment.

It may be perhaps of some service to Mr. More if I publically acknowledge that he used many arguments, to dissuade me from pursuing such an enquiry; or even be witness to any experiments, which might end in discoveries in any way disagreeable to his very good friends of the county of Devon.

In answer to Alcock's gibe that putty was made with lead as one of its constituents, he quoted from Chambers' Dictionary that putty is compounded of whiting and linseed oil beaten together to the consistence of a tough dough.

Meanwhile another pamphlet, this one anonymous, came from Exeter.* The writer claimed to have visited most of the pounds in that part of the country. He had found only one which had any lead in its structure, but he admitted that some were stone troughs, the stones being bound together with iron cramps with a little lead melted in at their ends to fasten them. He rather gives the game away by conceding that in common troughs 'if there are four pounds of lead 'tis the utmost; and of this, in any which I have seen, there has not been four square inches of superfices which come into contact with the Pomey'. He weighed lead and put it into some cider and left it for four weeks, after which he weighed it again and found no difference in the weight. He suggested that if there really was lead in the cider it might have got there in this manner. When the apples had been raked into heaps they became a favourite feeding place for birds, particularly if they had been long-standing and the weather had been cold. The birds would be a natural target for the farmer and the lead shot which was scattered over the heap might be the origin of the lead in the cider.

* An answer to Dr. Baker's essay concerning the cause of the Endemical Colic of Devonshire wherein the Cyder of that county is exculpated from the Accusation brought against it by that Gentleman, Exeter, printed by R. Trewman, behind the Guildhall, 1767. 


\section{R. M. S. McConaghey}

Francis Geach was quick to return to the fray, and this time he enlisted the aid of a Plymouth chemist, William Cookworthy*, who that year (1768) had opened a factory at Coxside in Plymouth and applied for a patent for the manufacture of hardpaste porcelain, thus starting a chain of events that was to lead to the foundation of the flourishing potteries of the Midlands. Cookworthy repeated the experiments of Saunders on samples of cider from the pound at Alphington and also from one at Sharpham which was also lead-lined and professed to find no lead in the samples. Geach was evidently annoyed, for Saunders had not been very complimentary and had attacked the great Huxham himself, 'For his portion of this curious compound, contained little, very little, more than a dull uninteresting, uninstructive, repetition of a vain unsubstantial theory, together with much false reasoning from his own private stock, and an abundance of misrepresentation.' To which Geach replied with some acerbity; 'My angry reprover must allow, that the reputations of those writers are founded on something else than a great name, and though at present no ancients, they will one day be so, and when so, will probably be no blind guides in what relates to the animal oeconomy.'

By a curious coincidence, Dr. Wall, one of the founders of the Worcester Royal Porcelain Company of 1751 was again brought into the controversy. Wall is quoted as saying that he had lately had two or three patients with colic occasioned by their having drunk cider made in a press covered over with lead.

The Reverend Thomas Alcock again entered the lists with a new edition of the essay that Francis Geach had appended to his first pamphlet. + 'Note', said Alcock, 'the English word, Reverend, when used by a polmic writer, as a title of address to his antagonist, always means irreverend, contemptible; just as the Latin Sacer Holy on some occasions signifies unholy, cursed, damned.' Saunders had questioned Alcock's qualifications for writing about a medical subject ' . . . My name was entered on the Physical line in Oxford, and ... I had opportunities, if I had but made proper use of them, of learning something both of Physic and Chemistry from a professor in those sciences, perhaps not inferior to this great doctor Saunders.' And he continues a statement claiming for the clergy a catholicism in learning which at that time was not unjustified. 'The clergy or priesthood, it is well known, have in all ages and all countries possessed a considerable share of the learning of the times, in which they lived, in consequence of their education, leisure, and seclusion from worldly employments; and have deserved well of the common wealth of letters, as being great promoters of arts and sciences. And therefore to censure them for meddling with other subjects, and confine them merely to theology, would be stopping up some of the principle sources of literature, and doing great injury to the public.'

* A reply to Dr. Saunders's Pamphlet relative to the Dispute concerning the Devonshire Cider. By Francis Geach, Surgeon at Plymouth and F.R.S. London, Printed for R. Baldwin, No. 47 in Pater-noster-Row, 1768. Of the 52 pages in this pamphlet 32 were by William Cookworthy. William Cookworthy, born Kingsbridge 1705 of Quaker parents. His father died in 1718 having lost his fortune in the South Sea Bubble. In 1719 William journeyed to London on foot to be apprenticed to the firm of Bevans, Chemists and Druggists. He was helped by Bevans to set up as Bevans and Cookworthy in Plymouth. He was unusually fluent in Latin and French and is said to have had a naturally charming and kindly manner.

$t$ Thomas Alcock A.M. The endemical colic of Devon, not caused by a solution of lead in the cyder. A particular reply is here given to Dr. Saunders' answer to cursory remarks; with some further remarks on Dr. Baker's essay on that subject. 


\section{Sir George Baker and the Devonshire Colic}

Saunders had accused Alcock of being a cider dealer and Alcock replied that he did indeed sell a hogshead of cider when they happened to make more than was needed for consumption in the family; yet there must have been some substance in Saunders' gibe, for Alcock when he wrote on the Cider Act had described himself as 'an A.M. and a cider maker'. In this second work Alcock produced much further evidence. Besides listing a number of pounds in Devon which had no lead lining and in which no lead had been used to fill the cracks, he produced evidence from his neighbours on the presence of lead in the pounds in Herefordshire and Worcestershire, some of which had been lead-lined and others in which molten lead had been poured around the cramps to make them watertight. He gives many other arguments in a long and skilfully arranged book. The work is undated but internal evidence suggests that it was published in late 1769 or in 1770.

As Baker had mentioned, many of the patients with the Devonshire colic were admitted to the hospital at Bath. In 1770, Rice Charlton, M.B., F.R.S., a physician at Bath, published An Inquiry into the Efficacy of Warm Bathing in Palsies. In his little book he makes an interesting classification of palsies that were treated in the hospital; a classification which was partly symptomatic and partly anatomical, and occasionally based on the supposed cause. He reported that over a period of thirteen years (17511764) there had been admitted to the hospital: 45 general palsies, 283 hemiplegics, 144 palsies of the lower limb, 3 dead palsies (all recovered), 5 shaking palsies, and 237 palsies from cider and bilious colics; 17 were from fever and 27 from rheumatism, 19 from accidents and 24 from extreme cold. Of the 237 caused by cider, Charlton remarks that only one came from Hereford and none from Worcester; all the rest were from the counties of Devon, Somerset, Gloucester and Cornwall. The wide area from which Bath drew its cases was due to the fact that the hospital was bound by its Charter to admit pauper patients from anywhere in the country. Two hundred and eighteen of the 237 cider and bilious colic patients were cured or benefited by their treatment and only five were discharged with their condition unchanged, nine died and four were improperly diagnosed; one took his discharge on his own responsibility. Charlton notes that nearly all the patients came to the hospital after their acute symptoms had been removed by treatment at their homes. (See table, p.358.)

Baker's thesis was soon accepted; that the colic of Devonshire was due to lead, was never again contested. When in 1778 James Hardy of Barnstaple wrote on the Colic of Poitou and Devonshire* he conceded that lead was the cause, quoting Charlton and other authorities to support that hypothesis. He wrote, 'I am convinced that the disease we call Painter's colic, the colica pictonum, the colic endmical to the county of Devon, and the dry belly-ache of the West Indies, are one and the same disease; and consequently must originate from one and the same cause'. Hardy believed that the lead came from the glaze in the pitchers in which the cider was stored. He reported a series of experiments in support of this theory. He accounted for the dry belly-ache of the West Indies from the fact that much Welch glazed ware was exported from Liverpool to the West Indies, as well as tin and tinned ware. The

* A candid examination of what has been advanced on the colic of Poitu and Devonshire with remarks on the most probable and experiments intended to ascertain the true causes of gout. By James Hardy, M.D. of Barnstaple, Devonshire. London, Printed by W. Mackintosh for T. Cadeli, in The Strand, 1778. 


\section{R. M. S. McConaghey}

A State of the Paralytic Patients admitted into the Bath Hospital, from May 1751 to May 1764

\begin{tabular}{|c|c|c|c|c|c|c|c|c|c|}
\hline \multicolumn{2}{|c|}{ Total Number admitted -1053} & \multirow{2}{*}{ 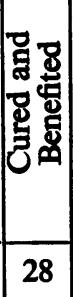 } & \multirow{2}{*}{ 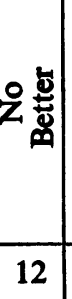 } & \multirow{2}{*}{$\frac{{ }_{\sharp}^{\sharp}}{\text { ̊̊ }}$} & \multirow{2}{*}{$\begin{array}{l}\text { 岛 } \\
\text { 음 } \\
\text { 을 } \\
1\end{array}$} & \multirow{2}{*}{ 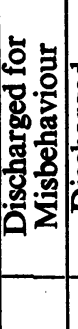 } & \multirow{2}{*}{ 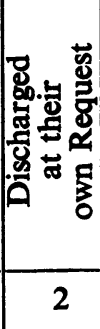 } & \multirow[t]{2}{*}{$\begin{array}{l}\text { ్ㅕㅇ } \\
\text { 몸 }\end{array}$} & \multirow{2}{*}{ 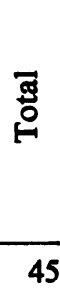 } \\
\hline 45 & General Palsies & & & & & & & & \\
\hline 283 & Hemiplegias & 204 & 41 & 12 & 20 & 1 & 4 & 1 & 283 \\
\hline 144 & Palsies of the Lower Limbs & 92 & 21 & 10 & 18 & 1 & 2 & & 144 \\
\hline 3 & Dead Palsies & 3 & & & & & & & 3 \\
\hline 5 & Shaking Palsies & 1 & 3 & & 1 & & & & 5 \\
\hline 237 & Palsies from Cyder and Bilious Colics & 218 & 5 & 9 & 4 & & 1 & & 237 \\
\hline 40 & Palsies from Mineral Effluvia & 38 & 1 & 1 & & & & & 40 \\
\hline 17 & Fevers & 13 & 2 & & 2 & & & & 17 \\
\hline 27 & Rheumatisms & 22 & 3 & 1 & 1 & & & & 27 \\
\hline 9 & Nervous Affections & 6 & 2 & & 1 & & & & 9 \\
\hline 2 & Suppression of the Menses & 2 & & & & & & & 2 \\
\hline 1 & Miscarriage & 1 & & & & & & & 1 \\
\hline 1 & Lying-in & 1 & & & & & & & 1 \\
\hline 19 & External Accidents & 16 & 2 & 1 & & & & & 19 \\
\hline 2 & Schrophula & 1 & 1 & & & & & & 2 \\
\hline 24 & Extreme Cold & 19 & 2 & & 1 & & 1 & 1 & 24 \\
\hline 11 & Palsies without an assignable Cause & 9 & 2 & & & & & & 11 \\
\hline 183 & Whole Cases were not properly described & 139 & 16 & 7 & 12 & 3 & 5 & 1 & 183 \\
\hline & TOTALS & 813 & 113 & 43 & 61 & 5 & 15 & 3 & 1053 \\
\hline
\end{tabular}

Cured and Benefited

813 Not Benefited $-240$

From CHARLTON, Rice. Three tracts on Bath Waters-With additional cases and notes by the Editor. Bath, 1774. 


\section{Sir George Baker and the Devonshire Colic}

potters of the time kept their secrets very close. Thomas Percival (1774)* had tried an experiment on a specimen of Burslam Pottery, the very beautiful polish of which inclined him to suspect that lead was used in the composition of the glazing. The specimen that he used was a piece of 'Queen's ware' similar to that which had been bought by Queen Caroline in 1762. In this Percival thought that he detected the presence of lead.

Hardy was far in advance of his time in calling for a Royal Commission: 'Their most Christian and Catholic Majesties would confer on their subjects, the most humane and essential obligations, by appointing a committee of physical gentlemen, with express directions to examine into the causes in those provinces where the disease is most prevalent ...'

When the ink had dried and the great controversy was over, what remained? Had Baker achieved his object and eliminated the cider colic from the land of his birth? We do not know. There is a general consensus of opinion that after a few years the disease became rare, but there is no statistical evidence to guide us. The Devonian is a conservative soul, and not easily stirred by the exhortations of foreigners. And yet he is cautious withall. A patient explaining how it was that he had selected one doctor for himself and another for his wife remarked that 'he didn't believe in putting all his eggs into one basket'; another, asked whether he believed in witches, said no, but he was taking no chances. And so it may have been with the lead round the millstones; removed but without acknowledging that there was any need to do so. Dr. Christian Budd (1815-1891) of North Tawton, nestling in the northern slopes of Dartmoor, is reported to have said in 1885 that when he started practice 40 years before, he occasionally saw cases of lead colic from drinking cider made in a lead press. 'The deleterious effects resulting from the use of lead were then generally acknowledged, and lead presses only remained in a few remote places, among small growers. They have now entirely disappeared, and Dr. Budd has not for many years seen any case of lead poisoning produced by cider.'14

In the copy of Alcock's Observations on that part of a late Act of Parliament which lays an additional duty on Cyder and Perry in the city of Exeter Library is a hand written note: 'I do not think that the Revd. Thomas Alcock made out his case "that the Devonshire Colic was not caused by the solution of lead", for when lead was no longer used in the pounds and presses from that time the colic disappeared. (signed) $\mathbf{H}$. $\mathbf{H}$. Treby'. Henry Hele Treby died in 1867 , so his evidence was not more than hearsay. In another note Treby claimed that Baker, Geach and Alcock were all friends of his family.

Where does Sir George Baker's work stand today in the development of scientific medicine? As an example of inductive reasoning it is superb; written in the most lucid prose, it is a model of how a scientific paper should be presented. It was published when England was on the brink of the industrial explosion which was to play such havoc with the lives of men, and yet it is a perfect example of a treatise on an industrial disease. Baker was a pioneer in the use of chemical analysis to solve an

* Observations and Experiments on the Poison of Lead, by Thomas Percival, M.D., Fellow of the Royal Society, and of the Society of Antiquaries in London. Haec tu Romane, caveto! Sed Romae quis non? Persius. London, Printed for J. Johnson, St. Paul's Churchyard, 1774. 


\section{R. M. S. McConaghey}

epidemical problem. Equally with the result achieved in the elimination of the endemical colic of Devonshire, its importance may be measured by the amount of discussion and opposition which it aroused. In focussing attention on the wider implications of lead poisoning in drinking vessels, as a contaminant in the manufacture and storage of food, and in water supplies, its influence was considerable.

In the history of all human endeavour there is always the moment when truth may be revealed and be understood. The age in which Sir George Baker lived was such. Seldom can there have been a more brilliant group of gentlemen in 'the physic line' gathered together in the small compass which comprised the intelligensia of eighteenthcentury London. In company with the great Dr. Johnson and his circle of poets, critics and artists, with Goldsmith, Dr. Burney and his daughter, with Reynolds and Garrick, walked Sir Joseph Banks, Fothergill, Lettsom, the Heberdens-father and son, Lind and Pringle, and the Hunters, William and John. What an age to have been alive in! Sir George Baker contributed to the graces of his age, a wit amongst wits, a sage in the company of sages.

\section{REFERENCES}

1. A handbook for travellers in Devon and Cornwall, 6th ed., rev., London, John Murray, 1865.

2. Munk, William, The Roll of the College of Physicians of London, London, Longman, Green, Longman \& Roberts, 1861, vol. II, p. 183.

Nichols, John, Literary Anecdotes of the Eighteenth Century, London, 1812-15, vol. III, pp. 70, 71.

3. Gentleman's Magazine, 1789, p. 950.

4. Aspinall, A., The Later Correspondence of George III, 1962, vol. 1, p. 383, letter number 465, dated London 19 July 1788.

Jesse, J. HenNaGe, Memoirs of the Life and Reign of King George III, London, Tinsley Brothers, 1867 , vol. III, p. 32ff.

5. Gentleman's Magazine, 1789, p. 950 (for salary).

6. Baker, Grorge, Medical Tracts read at the College of Physicians between 1767-1780, Collected by his son, 1818.

7. LeSLIE, ROBERT and TAYLOR, TOM, Life and Times of Sir Joshua Reynolds, With Notices of Some of his Contemporaries, London, John Murray, 1865, vol. 1, p. 325, 326.

8. Gentleman's Magazine, 1793, p. 510, letter from Academicus.

9. Gentleman's Magazine, 1793, p. 593.

10. British Museum Add. Ms. 19,242 f.38.

11. Huхнам, John, Observationes de aere et morbis epidemicis ab anno 1728-1748 . . . accedit opusculum de morbo colico Damnoniensi, London, 1739-1752.

12. Musgrave, Willam, De arthriditide anomala sive interna dissertatio, Exeter, 1707.

13. Listed by the Historical Manuscripts Commission. Royal Devon and Exeter Hospital Records, and held in the Devon County archives.

14. Willcocks, F., 'Notes on the Devonshire Colic', Trans. Devon Assoc., 1885, vol. 17, p. 331. 